\title{
Viable Airborne and Deposited Microorganisms inside the Historical Museum of Crete
}

Aerosol and Air Quality Research

\section{OPEN ACCESS}

Received: December 30, 2020 Revised: February 26, 2021

Accepted: March 8, 2021

${ }^{*}$ Corresponding Author:

katsivela@hmu.gr

Publisher:

Taiwan Association for Aerosol Research

ISSN: $1680-8584$ print

ISSN: 2071-1409 online

CC) Copyright: The Author(s).

This is an open access article distributed under the terms of the Creative Commons Attribution License (CC BY 4.0), which permits unrestricted use, distribution, and reproduction in any medium, provided the original author and source are cited.

\author{
Eleftheria Katsivela ${ }^{1 *}$, Louisa Raisi ${ }^{1,2}$, Mihalis Lazaridis ${ }^{2}$ \\ ${ }^{1}$ Hellenic Mediterranean University, Department of Electronic Engineering, 73133, Chania, \\ Greece \\ ${ }^{2}$ Technical University of Crete, School of Environmental Engineering, 73100, Chania, Greece
}

\section{ABSTRACT}

Measurements of the ambient viable microbe concentrations and of the microbial deposits on surfaces were performed in the Historical Museum of Crete over a period of two years. The levels of the airborne microbes in the museum rooms showed considerable variability, which was mainly related to the indoor activity (such as the number of visitors); indoor environmental conditions, including the air exchange rate; and exhibits' chemical compositions and storage conditions as well as the conservation treatments and cleaning techniques to which they had been subjected. An enrichment of acid-producing bacteria, heterotrophic bacteria, and autotrophic chemolithotrophic bacteria was encountered indoors, but a considerable decrease in the viable microbes, ranging from $5.5 \%$ to $76 \%$, was detected after the deployment of photocatalytic ionizers at the different measurement sites inside the museum. These ionizers mainly improved the air quality by reducing acid-producing bacteria, which potentially contribute to deterioration in cultural heritage objects.

The microbial colonization on 24 different painting materials and surfaces collected into model artwork essays, which had not received any preservation treatment, was examined for an exposure period of 18 months. The bacterial depositions on the paintings gradually colonized, depending on the material and the surface, resulting in concentrations of $10-300,000 \mathrm{CFU} \mathrm{cm}{ }^{-2}$. Although airborne fungi were observed in the exhibition rooms (at an average yearly concentration of 143 $\pm 115 \mathrm{CFU} \mathrm{\textrm {m } ^ { - 3 }}$ ), no fungal growth was detected on the majority of the painting materials in the model essays. Only the tempera, charcoal, wax pastel, and carton board displayed fungal colonization, which occurred very slowly and produced low concentrations of $70-200 \mathrm{CFU} \mathrm{cm}^{-2}$.

Keywords: Bioaerosols, Airborne bacteria and fungi, Indoor air quality, Photocatalytic ionizers, Museums

\section{INTRODUCTION}

The factors that determine the degradation of cultural heritage objects inside museums have been the focus of the scientific community due to their importance for the preservation of historical objects (Brimblecombe, 1990; Camuffo, 1998). Microclimatic conditions (e.g., temperature, relative humidity, light), air pollutants, and microbiological load are key parameters, which have to be studied for determining the suitability of the indoor environment for the preservation of the cultural heritage objects (Camuffo, 1998; Anaf et al., 2013; Ruga et al., 2015).

Microorganisms have been shown to present an important risk for cultural heritage objects, especially organic objects such as wood, woolen fabric, leather, and paper (Brimblecombe et al., 1999; Gauzere et al., 2013; López-Miras et al., 2013; Gauzere et al., 2014; Lazaridis et al., 2018). In addition, an important factor for the preservation of organic materials indoors in collections is the proper maintenance and climatic conditions of the museum microenvironment. Ruga et al. (2015) found a high variability of fungal bioaerosols in the crypt of St. Peter in Perugia with higher concentrations during summer. Biodegradation of art objects has been studied in the 
scientific literature and specific fungal and bacterial strains have been identified to deteriorate organic materials (Gallo, 1993; Lazaridis et al., 2015; Pasquarella et al., 2015; Di Carlo et al., 2016; Lazaridis et al., 2018). The deterioration depends on the structure of the material itself and the chemical composition of the substrate. Organic materials are mainly hygroscopic and sensitive to degradation processes (Nielser et al., 2010; López-Miras et al., 2013). An extensive scientific literature exists in respect to the biodegradation of organic materials such as paper, organic coatings and binding agents for paintings (McNamara et al., 2004; Bogomolova et al., 2007) but also in respect to degradation of inorganic objects (Cataldo et al., 2005).

The use of heating, ventilation, and air-conditioning (HVAC) systems is related with the accumulation of dust and microorganisms in museums (Camuffo, 1998). A previous study showed that high density of visitors in a museum resulted to accumulation of airborne bacteria and fungi in the air-handling unit of an air-conditioning system for both constant and variable air volume (Li et al., 2016). Furthermore, in the study by Li et al. (2016) observed an increase of the microorganism ambient concentration with an increase of the relative humidity. The concentration of airborne microorganisms in museums may also affect the health of the museum's personnel; consequently, a detailed assessment of microbial hazards has to be implemented specifically in the cultural heritage conservation laboratories (Gorny et al., 2016).

The concentration and variability of airborne microbes inside museums can be affected by several factors, such as the infiltration of the outdoor air, the human presence and activities (e.g., dust resuspension from visitors walking), bioaerosol emission by human activities like talking or coughing (Stelzenbach, 2002), indoor microclimatic conditions, the construction materials of the building itself, as well as, the composition of the cultural heritage objects.

The reduction of the microorganism concentration indoors at cultural heritage buildings is a challenge for the museum's personnel, and the protection of the exhibits. Disinfection of books using sprays enriched with benzalkonium chloride was investigated as a treatment for the reduction of fungi inside a public library (Micheluz et al., 2018).

In the current work, a study was performed to determine the concentration of viable airborne microbes for a period of two years in different indoor sites of the Historical Museum of Crete as well as outdoors, before and after the installment of air purifiers (photocatalytic ionizers). In addition, the microbial colonization on the surfaces of different painting materials and model essays was examined to evaluate their deposition and abundance on the surface of cultural heritage objects.

\section{METHODS}

\subsection{Sampling Locations}

Monthly measurements of the airborne microorganisms (bacteria and fungi) were performed for a period of two years (March 2014-February 2016) at the Historical Museum of Crete. The first year (March 2014-February 2015) measurements were conducted before the use of air purifiers (photocatalytic ionizers, Daikin MC70L air purifier, flow rate $170 \mathrm{~m}^{3} \mathrm{~h}^{-1}$, horizontal air inlet, vertical air outlet, 0.013 kw; https://www.daikin.eu/en_us/products/mc70l.html), whereas the second year (March 2015-February 2016) measurements were performed after the placement of the air purifiers. Continuous measurements of meteorological data were performed both indoors and outdoors (Glytsos et al., 2018). The Historical Museum is located in the center of the city of Heraklion close to the sea (Lazaridis et al., 2015). The museum collections consist of mainly organic materials, including cotton, wood, paper and paintings. The number of visitors can reach 1,500 persons per month during summer and about 300 persons per month in the winter, giving an average value of about 500 visitors per month. The museum is a mechanically ventilated building during visiting hours with an average air flow of $1,509 \mathrm{~m}^{3} \mathrm{~h}^{-1}$ (70-100\% of recirculation) in the whole museum, whereas the average natural infiltration rate is $220 \mathrm{~m}^{3} \mathrm{~h}^{-1}$. Table 1 presents the natural infiltration and mechanical recirculation conditions at the different measurement sites. The mechanical ventilation system uses $100 \%$ recirculation of air, and was operated only during the opening hours of the museum. Under standard conditions, $30 \%$ of the recirculated air was obtained from outdoors. The average natural infiltration in the whole museum was measured to be equal to $0.5 \mathrm{~h}^{-1}$. 
Measurements in air were performed outdoors (Site A) and at four sites indoors. The indoor sites include Site B (second floor, Ethnographic Collection room), Site C (ground level, main exhibition room close to the main entrance, A. Kalokerinos room), and Sites D I and D II (first floor, rooms of periodic exhibitions, Z. Portalakis I and II rooms) (Fig. 1). In Fig. 1 was also depicted the position of the photocatalytic ionizers, and the inlet and outlet of the mechanical ventilation system.

Table 1. Natural infiltration, heating, ventilation and air conditioning, mechanical recirculation, and number of placed photocatalytic ionizers at the corresponding measurements sites.

\begin{tabular}{|c|c|c|c|c|c|c|}
\hline Site & Floor & $\begin{array}{l}\text { Total } \\
\text { room } \\
\text { volume } \\
\left(\mathrm{m}^{3}\right)\end{array}$ & $\begin{array}{l}\text { Natural } \\
\text { infiltration } \\
\text { rate } \\
\left(\mathrm{m}^{3} \mathrm{~h}^{-1}\right)\end{array}$ & $\begin{array}{l}\text { Heating, } \\
\text { ventilation and } \\
\text { air conditioning } \\
\left(\mathrm{m}^{3} \mathrm{~h}^{-1}\right)\end{array}$ & $\begin{array}{l}\text { Recirculation } \\
\text { rate } \\
\left(\mathrm{m}^{3} \mathrm{~h}^{-1}\right)\end{array}$ & $\begin{array}{l}\text { Number of placed } \\
\text { photocatalytic ionizers } \\
\text { (one per } \sim 65 \mathrm{~m}^{3} \text { with } \\
\text { mean air flow rate } \\
170 \mathrm{~m}^{3} \mathrm{~h}^{-1} \text { ) }\end{array}$ \\
\hline $\begin{array}{l}\text { Ethnographic Collection room } \\
\text { (Site B) }\end{array}$ & Second & 476 & 750 & 2,500 & 2,500 & 7 \\
\hline A. Kalokerinos room (Site C) & Ground & 264 & 150 & 1,920 & 1,920 & 4 \\
\hline Z. Portalakis room I (Site D I) & First & 218 & 120 & 1,920 & 1,920 & 4 \\
\hline Z. Portalakis room II (Site D II) & First & 189 & 450 & 1,000 & 1,000 & 3 \\
\hline
\end{tabular}

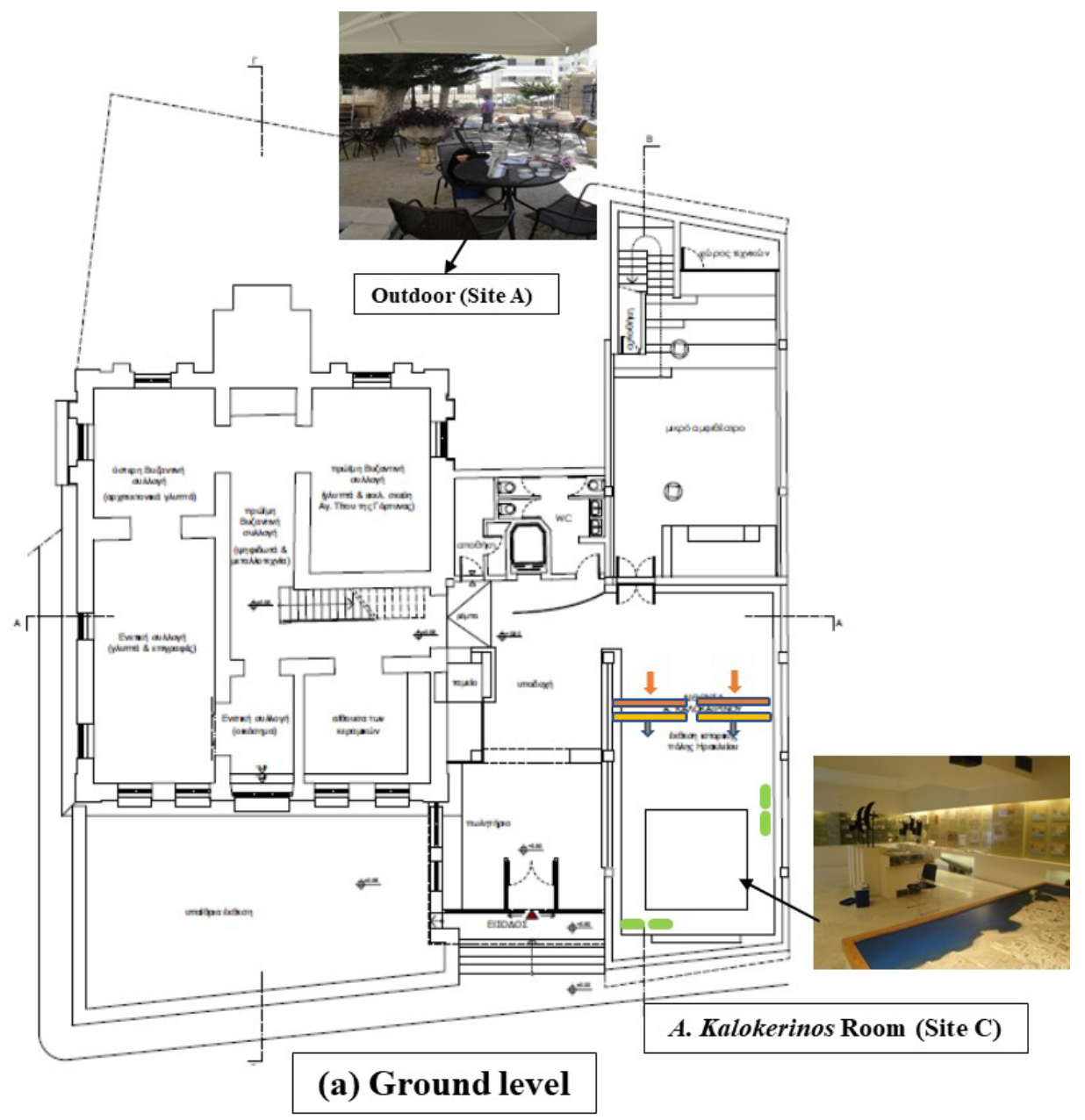

Fig. 1. Location and pictures of the sampling sites where measurements were performed. (a) Ground level: outdoors (Site A) and A. Kalokerinos room (Site C); (b) first floor: Periodical Exhibition Z. Portalakis rooms (Sites D I and D II); (c) second floor: Ethnographic Collection (Site B). The position of the photocatalytic ionizers indicated with a green color, whereas the inlet and outlet of the mechanical ventilation system were shown with blue and orange arrows, respectively. 

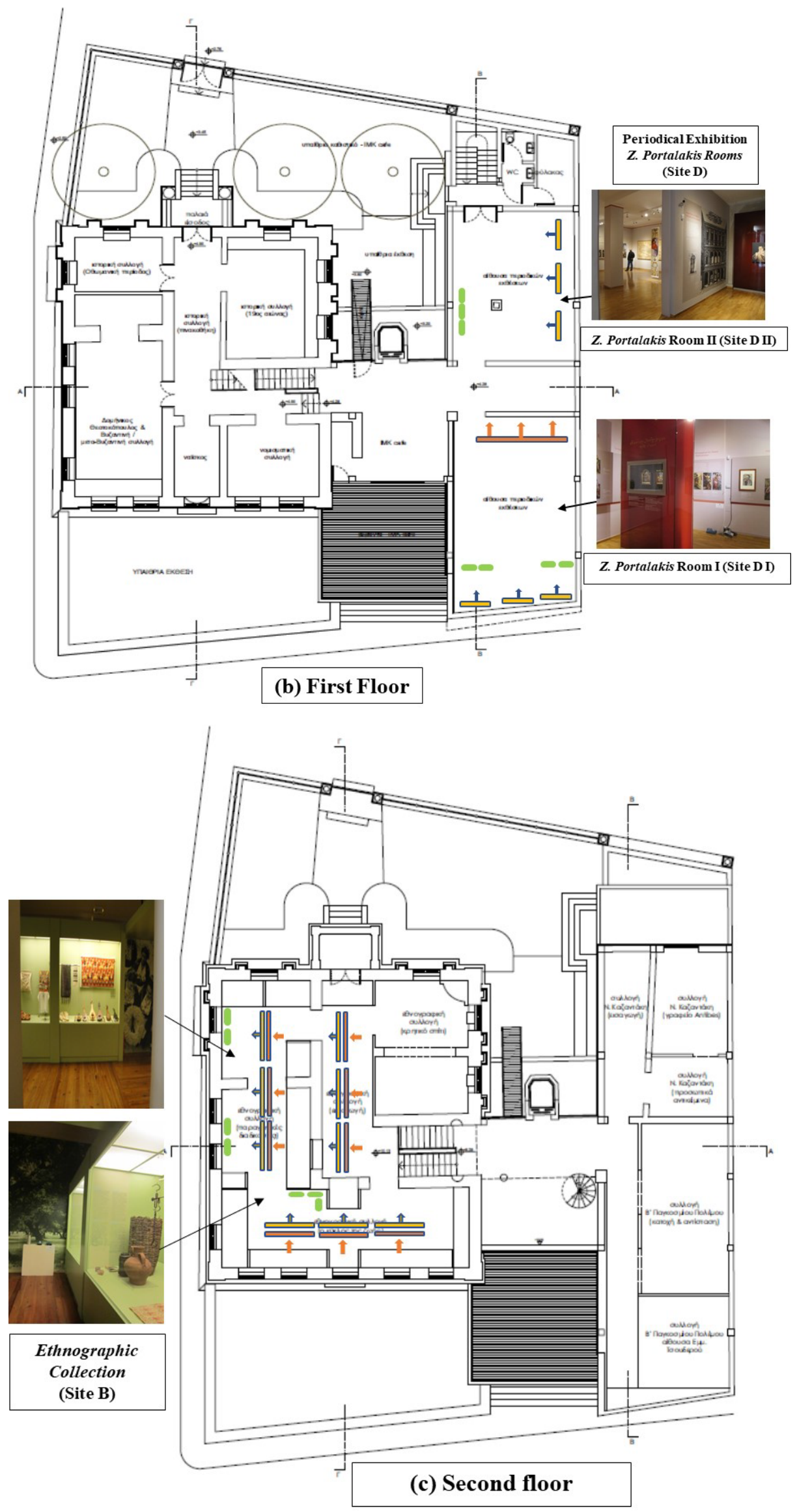

Fig. 1. (continued). 
The indoor sites correspond to different microclimatic conditions and were selected to determine the effects of mechanical ventilation, heating, ventilation and air conditioning, and air infiltration from the outdoor environment (Table 1). One sampling location was selected for each site, except Site D, where two locations (D I, D II) were chosen due to different mechanical ventilation settings. In Room D I there is sufficient ventilation through the roof and the floor, whereas in Room D II there is only ventilation on the floor level. In addition, Site B (Ethnographic Collection room) was chosen as an example of a museum room with efficient mechanical ventilation (Table 1), where all exhibits are placed inside showcases. Pictures of the measurement sites $A, B$, and $C$ are presented also in Fig. 1.

The indoor climatic conditions in the Historical Museum of Crete were well controlled during the opening hours, but the central heating and air-conditioning system was not in use after the closing of the museum. Continuous meteorological measurements (temperature $(T)$ and relative humidity $(\mathrm{RH})$ ) were performed indoors (Sites $\mathrm{B}, \mathrm{C}$, and $\mathrm{D}$ ) and outdoors (Site A) for the whole measurement period. The average values and standard deviation were: outdoors: $\mathrm{T}=19.2 \pm$ $3.5^{\circ} \mathrm{C}$ and $\mathrm{RH}=67.9 \pm 13.1 \%$; indoors: $\mathrm{T}=23.7 \pm 1.1^{\circ} \mathrm{C}$ and $\mathrm{RH}=52.8 \pm 3.8 \%$. The average indoor yearly values are similar to average seasonal values due to the controlled environmental conditions indoors during the museum opening hours. The temperature variation indoors was lower than outdoors, confirming the microclimate-controlling conditions inside the museum. As reported before (Glytsos et al., 2018), the average monthly variations of temperature and relative humidity between outdoors (Site A) and indoors (Site B) in the Historical Museum of Crete showed smaller difference during summer and larger deviations during winter. Although the temperature and relative humidity values indoors are close to the recommended conditions for cultural heritage buildings ( $50 \pm 5 \% \mathrm{RH}$ and $21^{\circ} \mathrm{C}$ (ASHRAE, 2013), they exceed the proposed limit values for the paper conservation as described by ASHRAE (2003, 2011, 2013). Only the measurements during March comply with the standards. This could be due to the fact that the central HVAC system was not used after the closing of the museum.

The effectiveness of the use of photocatalytic electrostatic precipitators (plasma ionizers) in the museum for improving the air quality in respect to the concentration of viable airborne microbes was further examined. The placement of photocatalytic ionizers (one Daikin MC70L air purifier per $65 \mathrm{~m}^{3}$ of room space) was performed to determine their efficiency to remove airborne microbes (Table 1).

\subsection{Bioaerosol Sampling and Measurements}

Measurements were performed one day per month, during the working hours of the museum, using the MAS-100 one-stage sampler with flow rate of $100 \mathrm{~L} \mathrm{~min}^{-1}$ (Merck, Germany) which collects viable particles larger than $1.1 \mu \mathrm{m}$. The sampling methodology is described in detail by Lazaridis et al. (2015). The collected air volume by the MAS-100 sampler varied from 50 to $250 \mathrm{~L}$. The referred air volumes of the collected samples using the MAS-100 sampler were optimized in experiments before, so that, for reliable results, the colony number per plate $(90 \mathrm{~mm}$ diameter agar Petri dishes) not to exceed the number of 80 . Each aluminum orifice stage was disinfected using wipes containing $70 \%$ isopropyl alcohol between collections of different samples.

Different selective microbiological growth media were used for the cultivation of viable airborne microbes (Lazaridis et al., 2015; Katsivela et al., 2017; Lazaridis et al., 2018). Two sequential repetitions on each specific growth medium were done at each site. The present study is focused on the collection and analysis of the following airborne microorganisms: i) opportunistic pathogenic, heterotrophic bacteria; ii) autotrophic chemolithotrophic bacteria; iii) acid-producing bacteria; and iv) fast-growing mesophilic fungi. Opportunistic pathogenic, heterotrophic bacteria were measured due to their possible health effects, whereas autotrophic chemolithotrophic bacteria were chosen to be analyzed as representatives of the autochthonous airborne microbes. In addition, acid-producing bacteria were examined because of the possibility to contribute to the deterioration of exhibits due to formation of acidic deposits, while mesophilic fast-growing fungi were determined due to their degradation potential.

The methodology of analysis for the viable, cultivable, airborne microorganisms is based on the cultivation of the air sampled microorganisms on specific microbiological growth media. The heterotrophic bacteria were cultivated in Tryptone Soy Broth (Merck, Germany) containing 1.5\% 
(w/v) agar at $37^{\circ} \mathrm{C}$ in the dark for $48 \mathrm{~h}$. Incubation temperature of $37^{\circ} \mathrm{C}$ was chosen for the determination of the airborne, heterochthonous (not indigenous to the area of present occurrence), opportunistic pathogenic, heterotrophic bacteria due to health-related interests. The autotrophic chemolithotrophic bacteria were cultivated in minimum mineral Tris phosphate agar (MMTPA; No. 457: Mineral Medium [Brunner]; Leibniz Institute DSMZ) without any carbon source at $37^{\circ} \mathrm{C}$ for 8 days. The acid-producing bacteria were cultivated in the Gluconobacter oxydans medium (No. 105; Leibniz Institute DSMZ) at $37^{\circ} \mathrm{C}$ in the dark for $8 \mathrm{~d}$. Acid-producing bacteria were counted only when form clear zones below the colonies. In parallel, viable mesophilic, fast-growing fungi were cultivated in Malt Extract Broth (Lab M, England) containing 1.5\% (w/v) agar at $20^{\circ} \mathrm{C}$ in the dark for $72 \mathrm{~h}$. Air samples were collected in two sequential repetitions on each specific growth medium in all indoor locations of museum (Sites A, B, C, D I, D II), and outdoors using a single sampler. The counted number of colonies was precisely corrected using the positive hole conversion tables, supplied by the manufactures of the used sampling instruments. Concentrations of airborne microorganisms were expressed as colony-forming units per cubic meter $\left(\mathrm{CFU} \mathrm{m} \mathrm{m}^{-3}\right)$.

\subsection{Microbial Deposition on Painting Surfaces}

Microbial deposits on painting surfaces were determined. Therefore, different painting materials and model essays were exhibited for eighteen months inside the museum. Two boards (a color board and a blackboard) with the following 24 different materials were used: textile, marker pen, pen ink, watercolors, aluminium foil, magazine, oil colors, Flo-Master pen, ink, colored tissue paper, tempera, acrylic colors, aquarelle, oil pastel, carton board, newspaper, chalk pastel, wax pastel, charcoal pencil, pencil, cotton undercoat with acrylic coating, charcoal, color pencil and unused cotton undercoat (Fig. 2). The boards were not treated using any preservation (e.g., toping of varnishes) to facilitate a more efficient deposition and colonization of airborne microbes. Varnishes have been used for the preservation of oil paintings against deterioration of the painting materials and surfaces from the $15^{\text {th }}$ century until today. The existence of viable microbial deposits on the surface of the essays was examined for each exposed material. Pieces from the boards with a surface area of $2.25 \mathrm{~cm}^{2}\left(1.5 \times 1.5 \mathrm{~cm}^{2}\right)$ were cut using a sterile titanium scrapple, and were aseptically placed in $3 \mathrm{~mL}$ of sterile phosphate buffered saline, $\mathrm{pH} 7.2$ (Sigma-Aldrich)

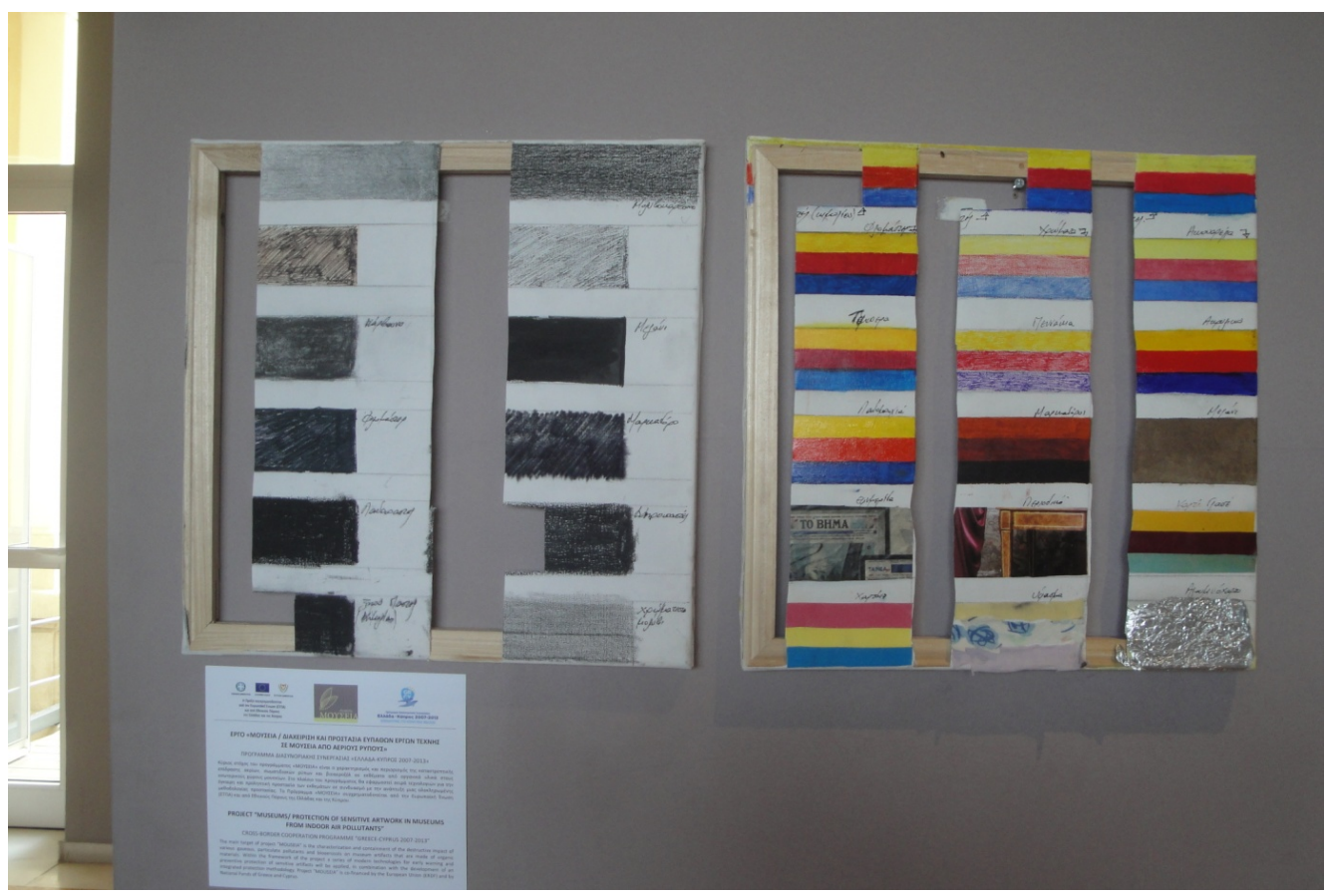

Fig. 2. Boards with painting materials and model artwork essays exposed in the museum that used for the determination of microbial deposits inside the Historical Museum of Crete (holes indicate sampled parts). Blackboard on the left and color board on the right. 
in glass test tubes with screw caps. After two days of equilibration under shaking at $200 \mathrm{rpm}$ at $30^{\circ} \mathrm{C}, 100 \mu \mathrm{L}$ of the serial diluted puffer was used for inoculation by the spread plate technique on the above-mentioned solid growth media. Tryptone Soy Agar was used for the cultivation of heterochthonous, opportunistic pathogenic, heterotrophic bacteria, and Malt Extract Agar for the cultivation of fast-growing fungi. Concentrations of viable microorganisms on surfaces were calculated in colony-forming units per square centimeter of essay $\left(\mathrm{CFU} \mathrm{cm}^{-2}\right)$.

\section{RESULTS AND DISCUSSION}

\subsection{Airborne Bioaerosol Measurements without the Use of Photocatalytic Ionizers}

The concentration levels of the airborne microbes before the installation of the photocatalytic ionizers during the one-year sampling (March 2014-February 2015) is shown in Fig. 3. A high variability in the measured microorganism concentrations was observed at each site. The range of concentration values varied from 215 to $5,345 \mathrm{CFU} \mathrm{m}^{-3}, 10$ to $1,612 \mathrm{CFU} \mathrm{m}^{-3}, 37$ to $3,545 \mathrm{CFU} \mathrm{m}^{-3}$

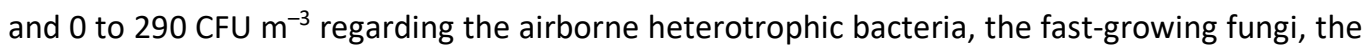
autotrophic chemolithotrophic bacteria, and the acid-producing bacteria, respectively. In comparison, lower bacterial concentrations and variability were detected outdoors (range of concentrations

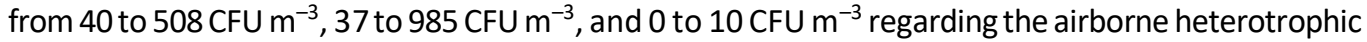
bacteria, the autotrophic chemolithotrophic bacteria, and the acid-producing bacteria, respectively). However, the airborne fast-growing fungi showed outdoors concentrations in the same range as indoors (71-1,490 CFU $\mathrm{m}^{-3}$ ). According to the Italian Ministry of Cultural Heritage and Activities and Tourism (MiBAC) (1998) threshold values for the protections of cultural heritage objects were proposed. The recommended concentrations of heterotrophic bacteria and fungi have to be below 750 and 150 CFU m ${ }^{-3}$, respectively. These recommendations agree with the studies presented by Parchas (2008), and Flieder and Capderou (1999) which recommend concentrations

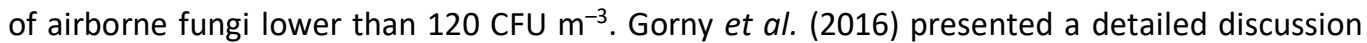
concerning threshold limit values. These proposed threshold values were exceeded for heterotrophic bacteria and fungi inside the measurement sites of the Historical Museum of Crete during some of the measurement periods as shown in Fig. 3. The average one-year indoor concentration of cultivable heterotrophic bacteria was $999 \pm 821 \mathrm{CFU} \mathrm{m}^{-3}$, whereas the average one-year indoor concentration of cultivable fungi was $184 \pm 210 \mathrm{CFU} \mathrm{m}{ }^{-3}$. In comparison, the average one-year outdoor concentration of the heterotrophic bacteria and fungi was $218 \pm 159 \mathrm{CFU} \mathrm{m}^{-3}$ and $303 \pm$ $393 \mathrm{CFU} \mathrm{\textrm {m } ^ { - 3 }}$, respectively. Due to reported exceedances of the recommended values a further study for the reduction of the observed values of airborne microorganisms was performed. This study was elaborated using air-cleaning systems, such as photocatalytic ionizers as described in the materials and methods section.

The measured average sum of one-year microbial concentration measurements at all indoor sites were in the same range varying from 2,144 $\pm 1,591 \mathrm{CFU} \mathrm{m}^{-3}$ (minimum average one-year concentration at Site D I) to $2,719 \pm 1,561 \mathrm{CFU} \mathrm{m}^{-3}$ (maximum average one-year concentration at Site D II). In accordance in another reported study in the Louvre Museum, the indoor airborne bacterial community remained stable over time with a common microflora of more than $50 \%$ (Gauzere et al., 2014). The higher concentrations measured at Site D II (Z. Portalakis room II), may be due to lower infiltration rate (natural ventilation equal to $450 \mathrm{~m}^{3} \mathrm{~h}^{-1}$ and mechanical ventilation with recirculation equal to $1,000 \mathrm{~m}^{3} \mathrm{~h}^{-1}$ ). In comparison at Site $D$ I the infiltration rate was higher (natural ventilation equal to $120 \mathrm{~m}^{3} \mathrm{~h}^{-1}$, and mechanical ventilation with recirculation equal to $1,920 \mathrm{~m}^{3} \mathrm{~h}^{-1}$ ) (Table 1). At Site D I the total air movement (natural and mechanical) was $2,040 \mathrm{~m}^{3} \mathrm{~h}^{-1}$, whereas for D II was $1,450 \mathrm{~m}^{3} \mathrm{~h}^{-1}$ (Table 1). Specifically, the mechanical ventilation of $D$ I was almost two times higher than $D$ II. The average sum of one-year microbial concentration measurements was considerably lower outdoors (Site A) and equal to $968 \pm 907 \mathrm{CFU} \mathrm{\textrm {m } ^ { - 3 }}$.

A seasonal variability was observed at the different sites indoors, which is however different for each site (Fig. 4). This highlights the variability of the microorganism concentration in air. High seasonal variability of airborne microbial concentrations was measured both indoors in the different exhibition rooms and outdoors. Furthermore, the indoor airborne bacterial concentrations were higher than outdoors in the majority of cases, except during the summer period in the $A$. 


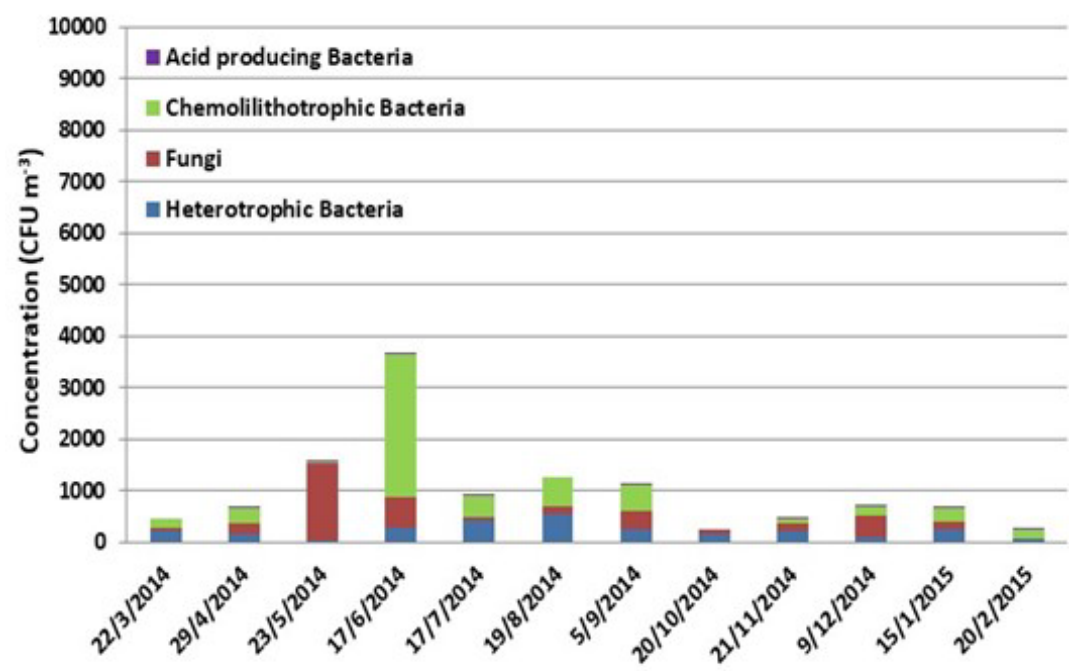

(a)

Sampling date

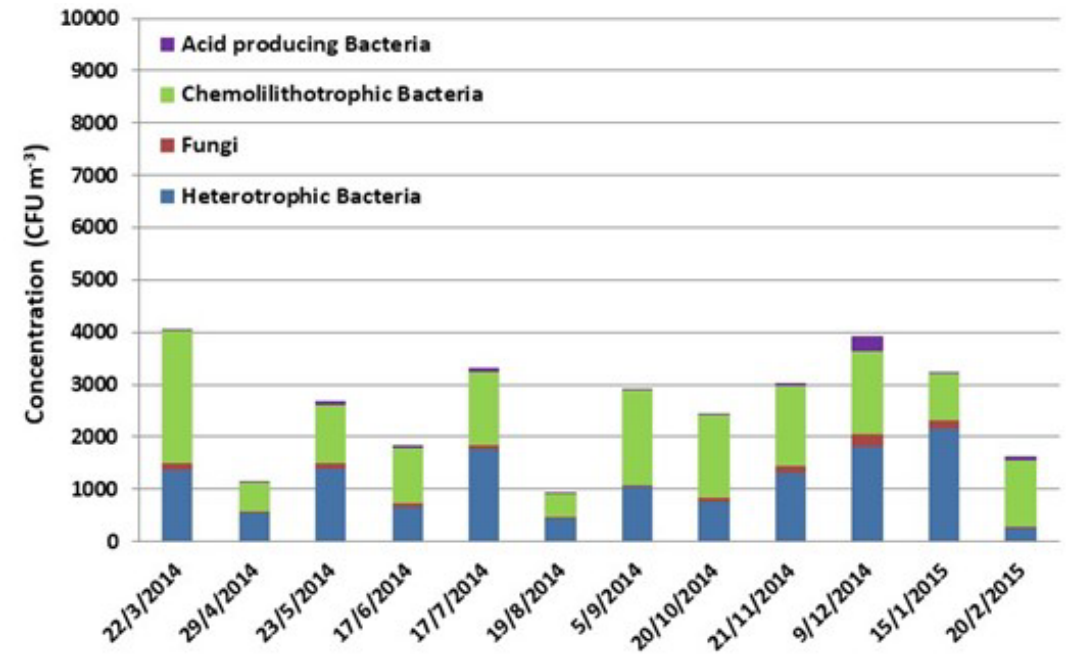

(b)

Sampling date

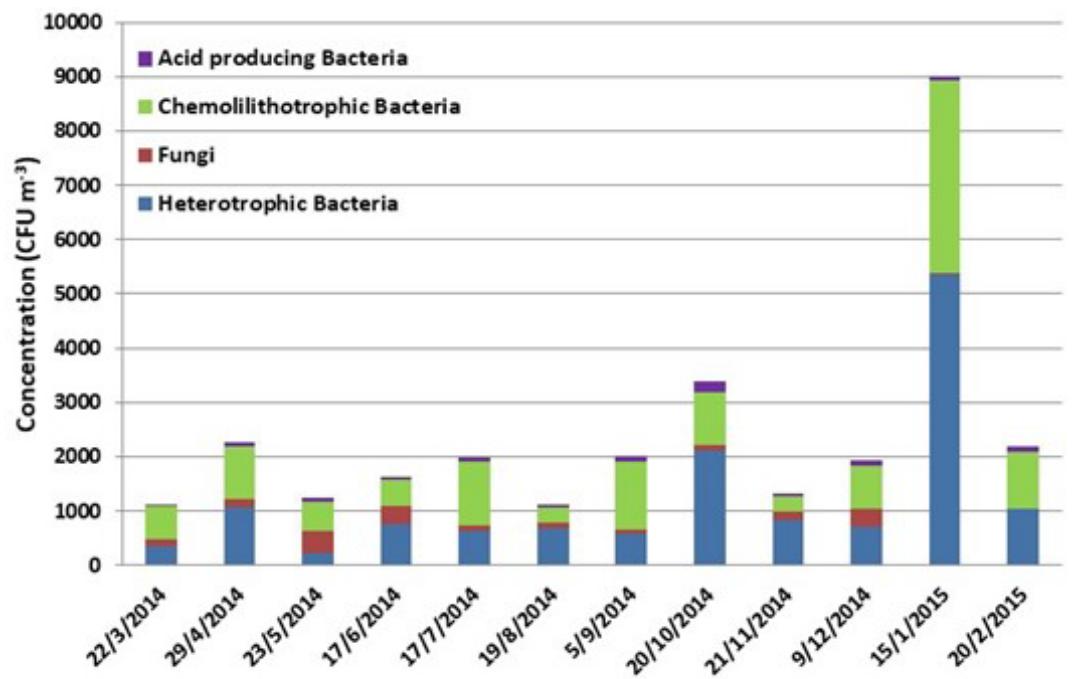

(c)

Sampling date

Fig. 3. Monthly measurements of viable airborne microorganisms (March 2014-February 2015) at the Historical Museum of Crete: (a) outdoors (Site A), (b) Ethnographic Collection room (Site B), (c) A. Kalokerinos room (Site C), (d) Z. Portalakis room I (Site D I), and (e) Z. Portalakis room II (Site D II). 


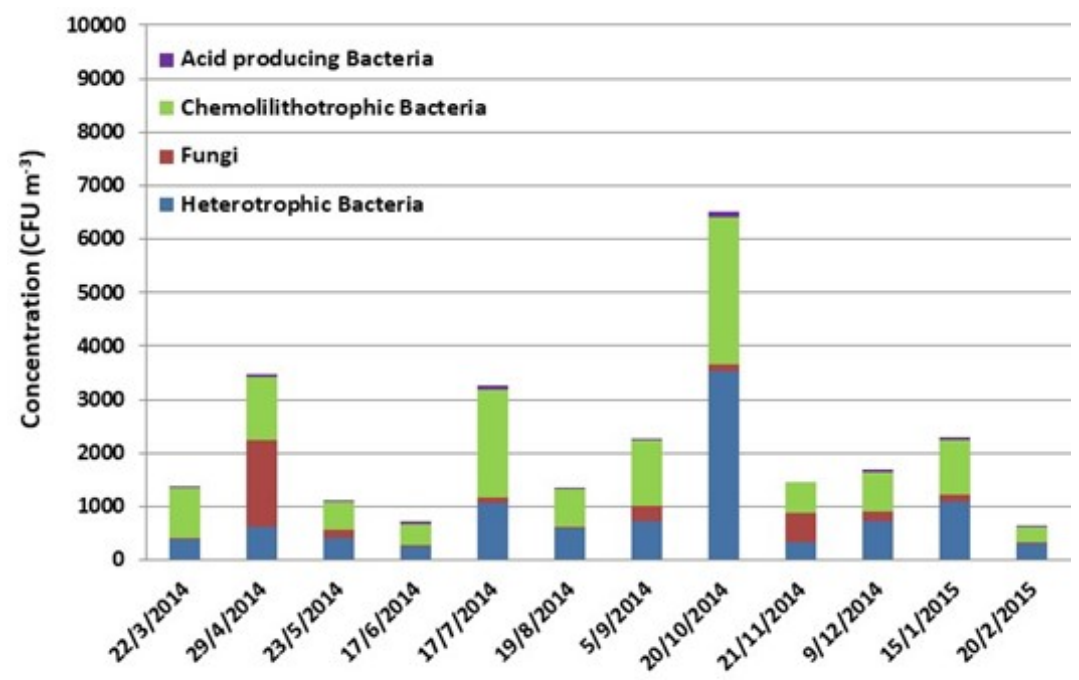

(d)

Sampling date

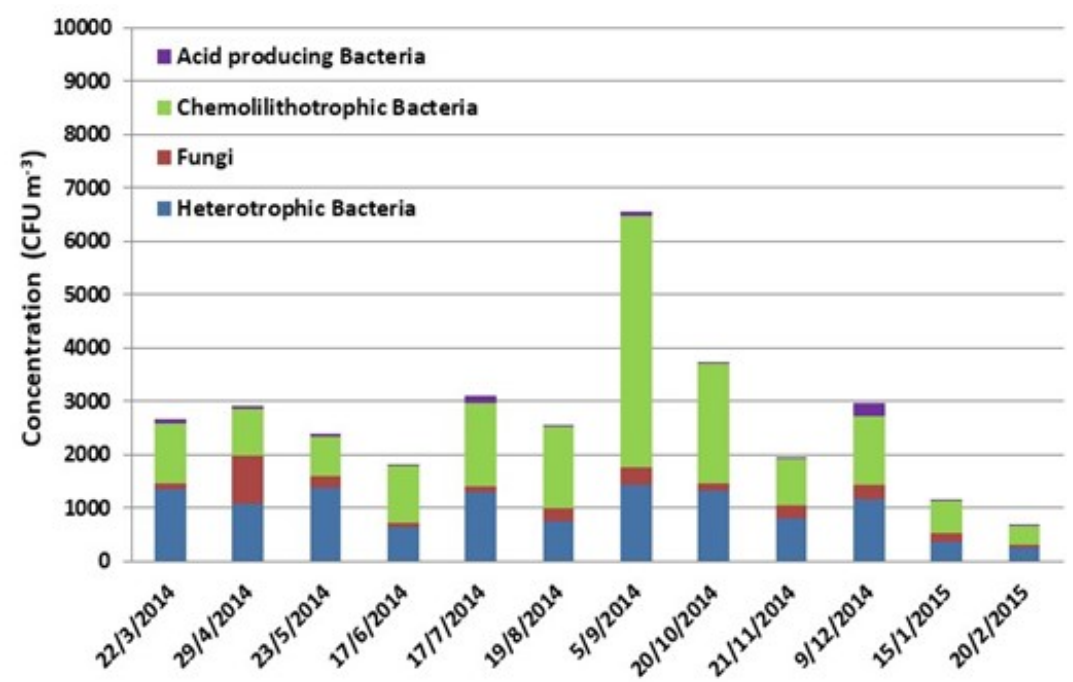

(e)

Sampling date

Fig. 3. (continued).

Kalokerinos and Z. Portalakis I and II rooms, where the concentration of chemoautotrophic bacteria was higher outdoors. In contrast, a relatively low concentration of airborne fungi was measured indoors. These results agree with previous measurements in the Historical Museum of Crete as well as in other cultural heritage collections (Lazaridis et al., 2015; Lazaridis et al., 2018).

Although Ruga et al. (2015) found higher concentrations of airborne fungi in summer in the crypt of St. Peter in Perugia, in the present study, the summer period showed lower microorganism concentrations indoors in respect to other seasons (Fig. 4). As shown, the highest concentrations during spring and summer were measured in the Ethnographic Collection, whereas the $\mathrm{Z}$. Portalakis room II (Site D II) and the A. Kalokerinos room (Site C) showed the highest microbial concentrations during autumn and winter, respectively. Although similar concentrations were observed between Site D I and Site $C$ during spring and summer, differences were measured during autumn and winter. In comparison, the highest outdoor microbial concentrations were measured during the summer period, whereas the lowest concentrations were observed during the winter period.

The enrichment of airborne microorganisms indoors was studied also in respect to other activities, which may result to reduction of the emission sources such as cleaning and restriction to museum visitors. Fig. 5 shows the effects of room cleaning and visitor presence in Site D I. 


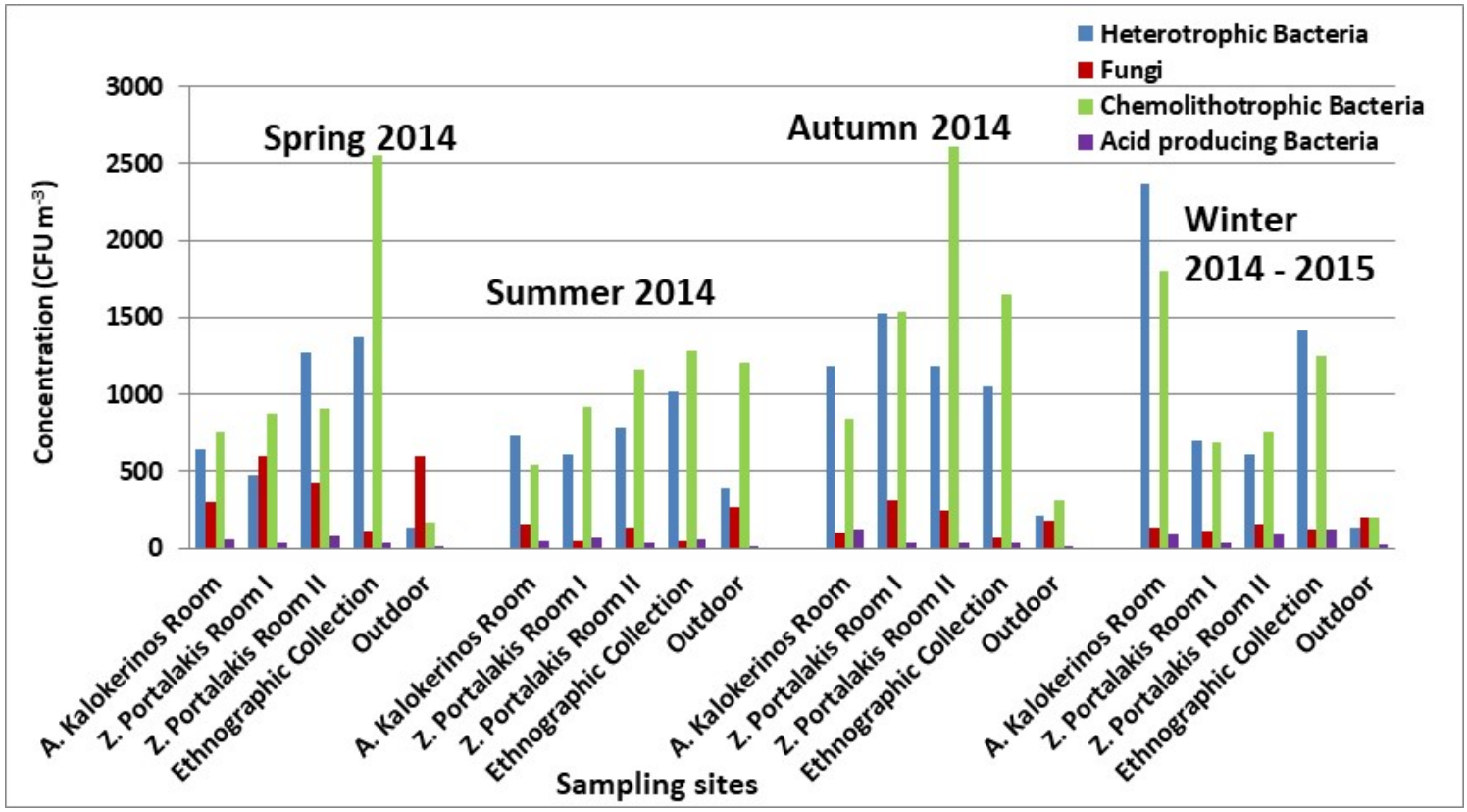

Fig. 4. Seasonal average concentrations of viable, cultivable airborne microorganisms in the Historical Museum of Crete at the different measurement sites.

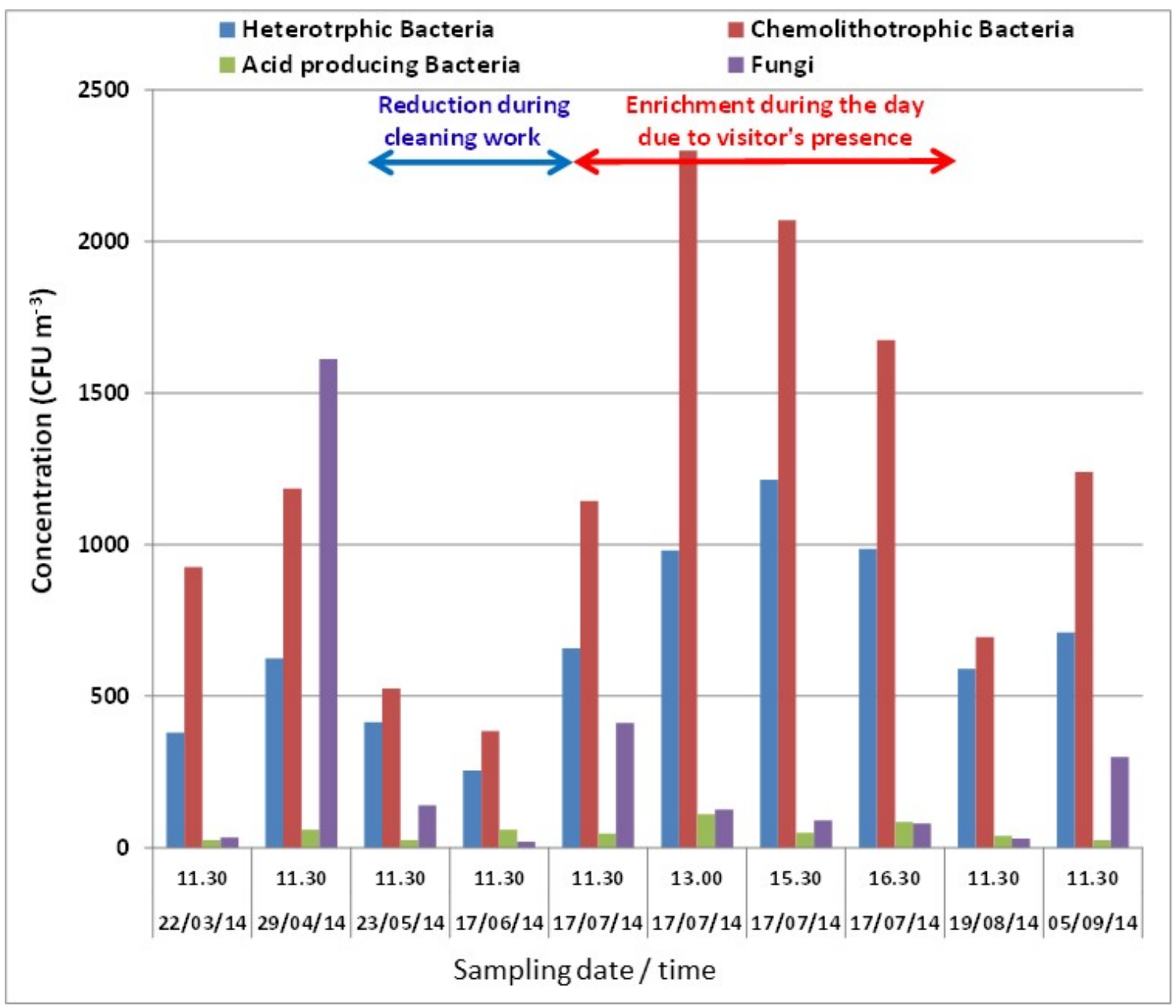

Fig. 5. Enrichment of airborne microorganisms in Z. Portalakis room I (Site D I) associated with the visitor's presence and room occupation. 
A considerable reduction of the concentration of airborne microbes was observed during the cleaning work performed from May to June 2014, when no visitors were allowed to access the site. Contrary, an enrichment of airborne microbes was measured during the opening hours of the museum from 11:30 a.m. to 3:30 p.m. at the $17^{\text {th }}$ of July 2014 due to the increase of visitor's presence. However, no statistically significant correlation between airborne microbes and number of daily visitors could be found in any of the indoor exhibition sites, although higher concentrations of viable microbes were generally encountered during the opening hours of the museum when visitors are present. An implication of these measurements is the necessity of the control of the intensity of the flow rate of the mechanical ventilation system in the museum. The intensity has to be increased during noon when a major part of visitors has been entered in the museum as well as during the occurrence of other activities indoors.

As reported before (Stelzenbach, 2002), building occupants are a major source of bacterial aerosols indoors. Human activities like talking, coughing, and walking are some of the possible emission sources of microbes in the air. In accordance, the common bacterial airborne microbial community in the Louvre Museum was related to human-associated microflora (Gauzere et al., 2014). In addition, building materials, components, and surfaces can serve as indoor sites of microbial colonization and subsequent dispersal into the air though the natural and mechanical ventilation (Lightthart and Stelzenbach, 1994; Buttner et al., 1999), and the occupant's activities (Reynolds et al., 1990; Buttner and Stelzenbach, 1993; Stelzenbach, 2002).

The enrichment of airborne microbes can be also depicted from their average seasonal indoorto-outdoor $(\mathrm{I} / \mathrm{O})$ concentration ratio as shown in Fig. 6 . As seen, the seasonal average I/O ratios varied among the different groups of microbes. The acid-producing bacteria showed the highest I/O ratios (13-92) in all indoor sites during autumn, spring and summer. The potential pathogenic heterotrophic bacteria were the group of bacteria that showed the next high I/O ratios (2-21), followed by the autotrophic chemolithotrophic bacteria (1-14) in all indoor sites. The lowest enrichment of airborne microbes was observed during winter. The enrichment of acid-producing bacteria indoors may result to the deterioration of exhibits in the museum due to acidic deposits on the exhibits. It is known that acids are intermediates or dead-end metabolites of acidproducing bacteria (Maier et al., 2000). Absence or very low enrichment of airborne fast-growing fungi (I/O ratio: $0.1-3$ ) could be detected inside the Historical Museum of Crete during the measurement period. These results are in accordance to measurements in other cultural heritage

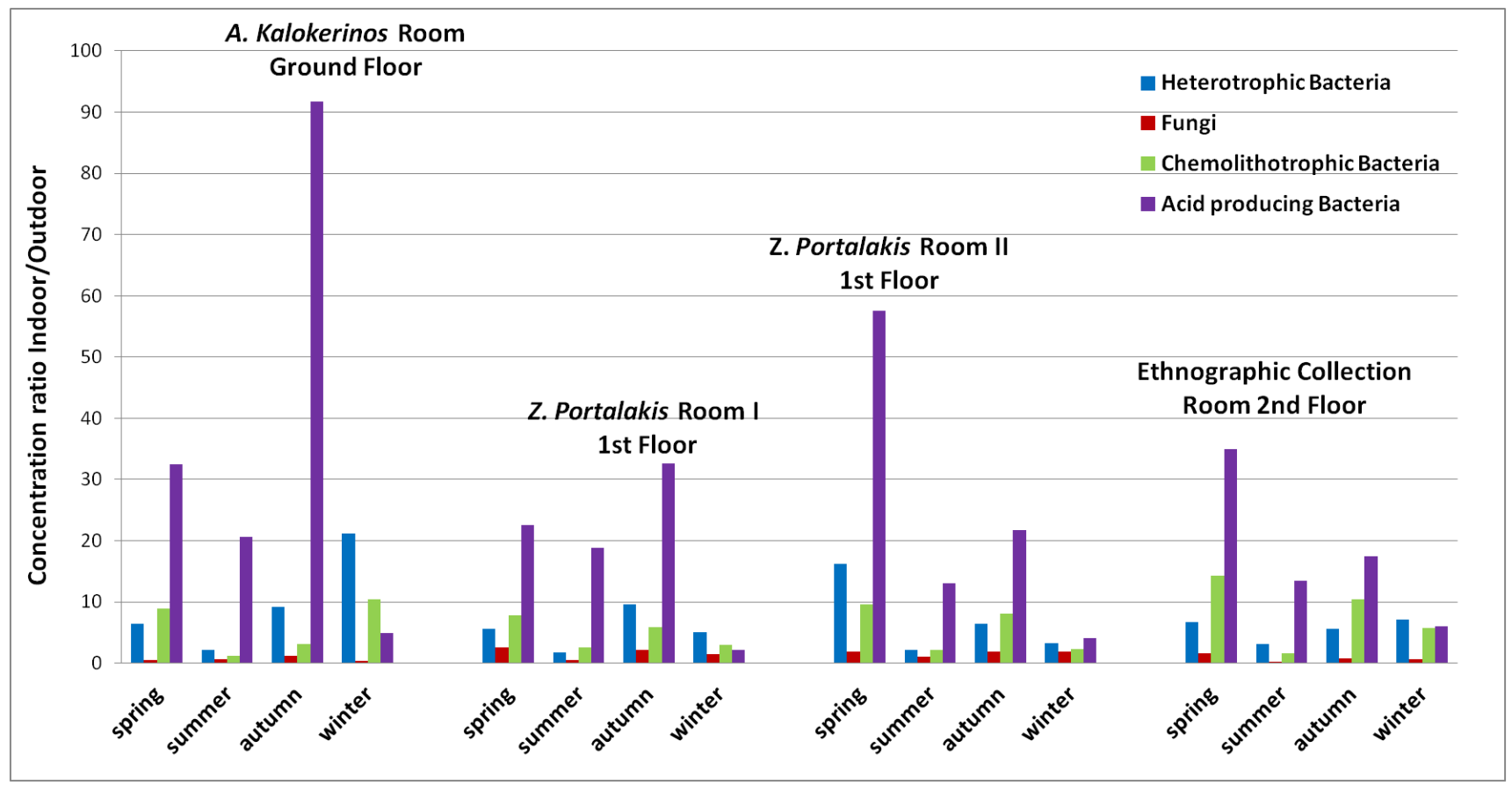

Fig. 6. Seasonal average indoor-to-outdoor (I/O) concentration ratio of viable airborne microorganisms in the different indoor sites of the museum. 
collections where the microclimatic conditions are well controlled by HVAC systems, probably due to absence of fungal emission sources indoors and the low outdoor air supply (Gauzere et al., 2014; Lazaridis et al., 2015; Lazaridis et al., 2018). Petushkova and Kandyba (1999) found also that the majority of the airborne microbes inside the Moscow Kremlin cathedrals were capable of producing acids. In addition, biodegradation of porous inorganic materials is reported to be caused by the formation of carbonic acid (formed by the dilution of carbon dioxide in water), and by other acids being metabolites of microbes (Karyś and Ważny, 2007). Increased enrichment of airborne fungi (Ruga et al., 2015; Lazaridis et al., 2018) and bacteria (Brągoszewska et al., 2018) in naturally ventilated rooms was observed in comparison to rooms equipped with HVAC systems.

\subsection{Airborne Bioaerosol Measurements during the Use of Photocatalytic Ionizers}

Fig. 7(a) presents the one-year average values of the measured microbial concentrations before and after the installation of photocatalytic ionizers inside the museum. In general, the use of photocatalytic ionizers improved considerably the indoor air quality in respect to the presence of viable airborne microbes. The indoor conditions were kept constant during the experimental campaign; temperature and relative humidity were controlled indoors and the visitors were not allowed to enter the measurement site $30 \mathrm{~min}$ before the measurements started. The photocatalytic ionizers had a mean air flow rate $170 \mathrm{~m}^{3} \mathrm{~h}^{-1}$ and the ventilation conditions were kept constant (Table 1).

However, differences in the reduction of airborne microorganisms were encountered after the deployment of the photocatalytic ionizers in the four indoor sites. The one-year average decrease of the sum concentration of the cultivable airborne microbes varied from $5.8 \%$ to $76 \%$. The microbial removal efficiency of the photocatalytic ionizers depends, probably, not only on the installation of the correct number of air purifiers (one ionizer per $65 \mathrm{~m}^{3} \mathrm{room}$ space; Table 1) but also on the total aeration rate of the room, as well as, on the emission rate of the airborne microbes (visitor presence and occupant's activities, as reported before in the section "Airborne bioaerosol measurement without the use of photocatalytic ionizers"). However, these findings are limited to the measurement period and have to be treated with caution.

As shown in Fig. 7, the best air quality conditions were achieved at Site B (Ethnographic Collection room), where the sum concentration of airborne microbes was even lower than the outdoor level. Thus, the highest decrease of airborne viable microbes (76\%) was encountered at Site $B$, where besides the placed ionizers, the aeration rate is the highest in the museum (natural ventilation equal to $750 \mathrm{~m}^{3} \mathrm{~h}^{-1}$, and mechanical ventilation with recirculation equal to $2,500 \mathrm{~m}^{3} \mathrm{~h}^{-1}$ ) (Table 1). In addition, as mentioned before, all exhibits at Site B are placed in closed showcases. In contrast, the lowest decrease of viable airborne microbes (5.5\%) was measured at Site D II ( $Z$. Portalakis room II), which had the highest concentration of airborne microbes in the whole museum before the deployment of the ionizers and the lowest aeration rate (Table 1). However, two sites with similar aeration rate (Site D I, and Site C; Table 1) showed large deviations regarding the reduction of the sum concentration of viable microbes. At Site D I was encountered microbial removal efficiency of $39 \%$, whereas at Site C was measured only a reduction of $10 \%$. This implies the need of an optimum control of the flow rate of the mechanical ventilation system in the museum for the reduction of the enrichment of microbes in respect to human activities as well as the use of showcases for the protection of artworks.

Fig. 7(b) shows also the seasonal average concentrations of viable, cultivable airborne microorganisms in the museum after the placement of photocatalytic ionizers. Even though the placement of the photocatalytic ionizers resulted to the reduction of the concentration of microorganisms indoors, it did not affect the indoor variability at the different sites, as well as, the seasonal variability.

Furthermore, the calculation of the one-year average I/O concentration ratios of each category of microbes at every site, before and after the placement of photocatalytic ionizers, was performed for a better evaluation of their efficiency (Fig. 8). Significant reduction of the one-year average I/O ratio from 26.4 to 3.0 was observed for acid-producing bacteria. Since acid-producing bacteria are a risk factor for the degradation of organic objects, the use of photocatalytic ionizers 

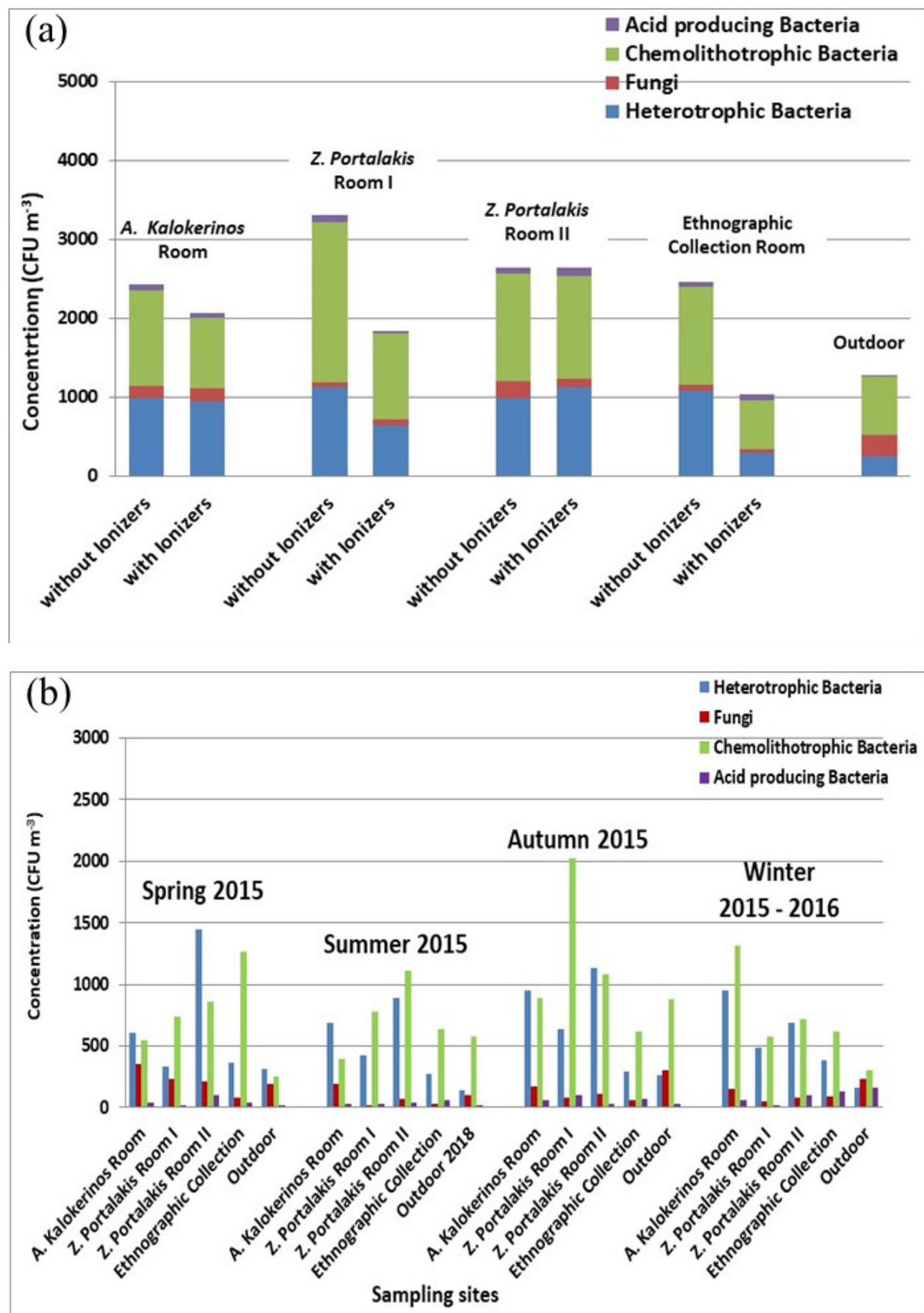

Fig. 7. (a) One-year average decrease of the ambient concentration of microbes (CFU $\mathrm{m}^{-3}$ ), and (b) seasonal average concentrations of viable, cultivable airborne microorganisms at the different measurement sites after the placement of photocatalytic ionizers (spring 2015 through winter 2015-2016).

improved the air quality by reduction of their concentration (Fig. 8). This was achieved by decreasing the average $\mathrm{I} / \mathrm{O}$ concentration ratios of the acid-producing bacteria by a factor of 8.8 in all rooms. In comparison, a moderate reduction of the one-year average I/O concentration ratios by a factor of 1.5 was obtained after the application of the photocatalytic ionizers for all the other measured viable airborne microbes (heterotrophic bacteria, fast-growing fungi, and autotrophic chemolithotrophic bacteria).

In agreement, Park et al. (2016) reported differences on the killing efficiency of the microbial population of different bacterial species by air-purifying ionizers. The authors showed that 


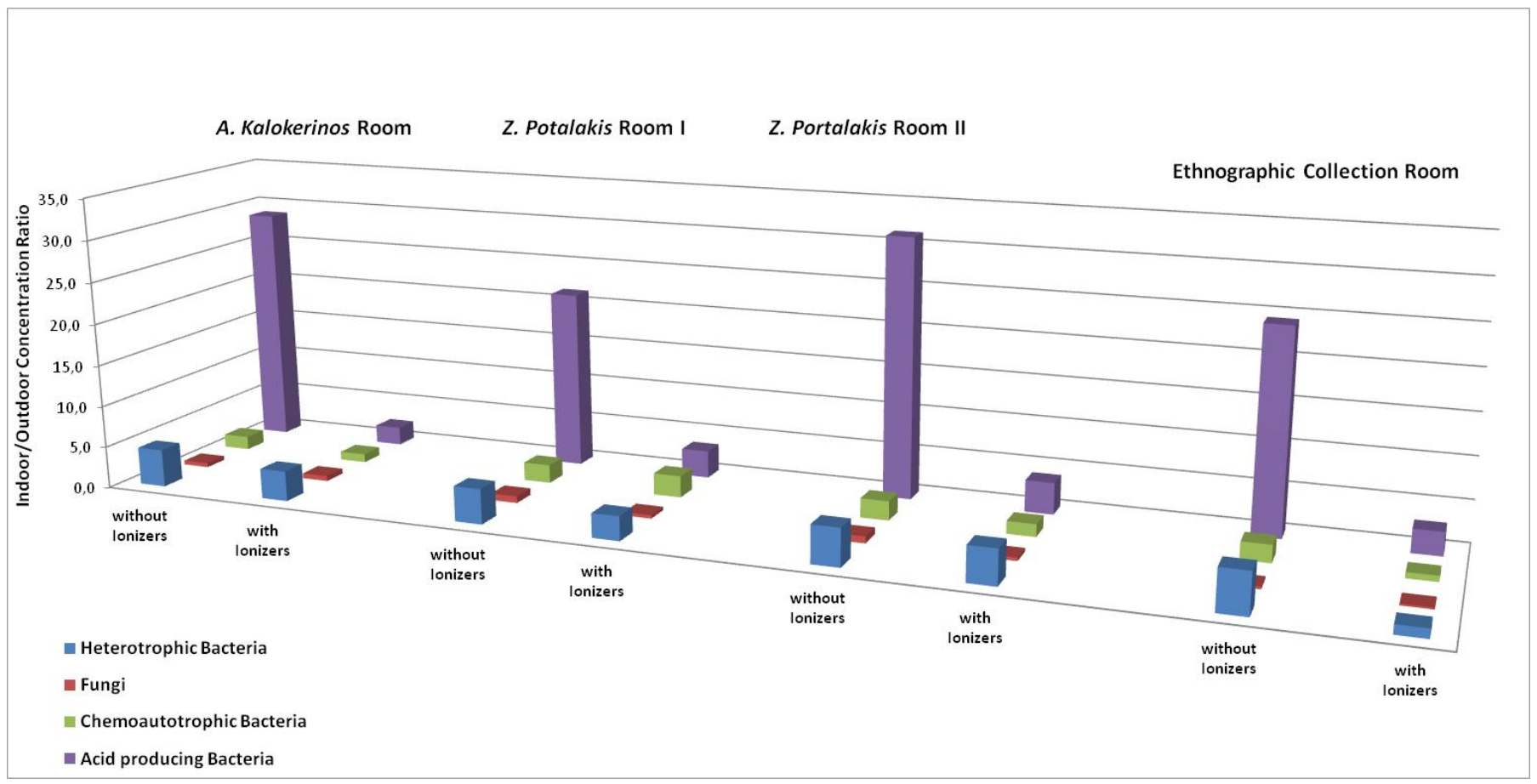

Fig. 8. Indoor-to-outdoor $(\mathrm{I} / \mathrm{O})$ concentration ratio at the different measurement sites with and without the use of ionizers for different categories of microbes.

ionizers cause bactericidal effect due to oxidative damage of cells and DNA by the generated negative and positive ions. Pushpawela et al. (2017) also observed a reduction of ultrafine particles with the use of ionizers in indoor environments. The authors concluded that air ionizers are more effective in removing ultrafine particles than high-flow air filters in rooms larger than $25 \mathrm{~m}^{3}$. In addition, it was also observed that the particle removal efficiency is decreased as the room volume is increased.

\subsection{Microbial Colonization on Different Painting Substrates}

Two boards (a color board and a blackboard) consisting of different essays painted with different materials, without the use of any preservation treatment, were placed on a wall at Site D II (Z. Portalakis room II) in the museum for an exposure period of 18 months (2014 July 162016 June 1; Fig. 2). The objective was to determine the microbial deposits on the different materials during the placement of the boards in the museum. The colonization and growth of microbes on the surfaces can be an important source of emission of bioaerosols (such as spores, cellular debrides, toxins, allergens) that can be potentially dangerous for human health (Stelzenbach, 2002). On the other hand, microbial surface colonization can cause deterioration of artworks (Urzi et al., 2001; López-Miras et al., 2013). A sample from each material was cut at the beginning (control), after 7, 10,16, and 18 months of exposure to determine the gradual enrichment of the materials and surfaces with viable, cultivable microbes (heterotrophic bacteria and fungi). The results from the bacterial colonization on paintings showed a clear correlation between the colonization and survival of viable heterotrophic bacteria on the exhibits' surfaces and the chemical composition of the used painting materials of the model essays. The deposition of viable heterotrophic bacteria on the 24 different painting materials and surfaces of model essays showed a gradual colonization, specific to the materials and surfaces, mostly followed by a reduction of microbial population after 18 months of exposition (Fig. 9). The data analysis has shown, that the bacterial colonization can be divided in three main categories:

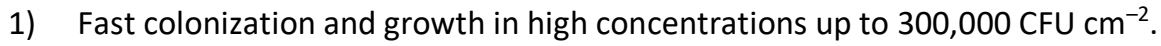

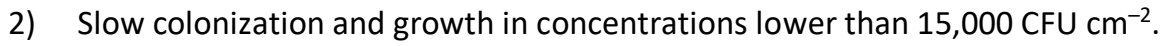

3) Very slow colonization (earliest detection after 10 months of exposition) and growth in concentrations lower than $5,000 \mathrm{CFU} \mathrm{cm}^{-2}$. 


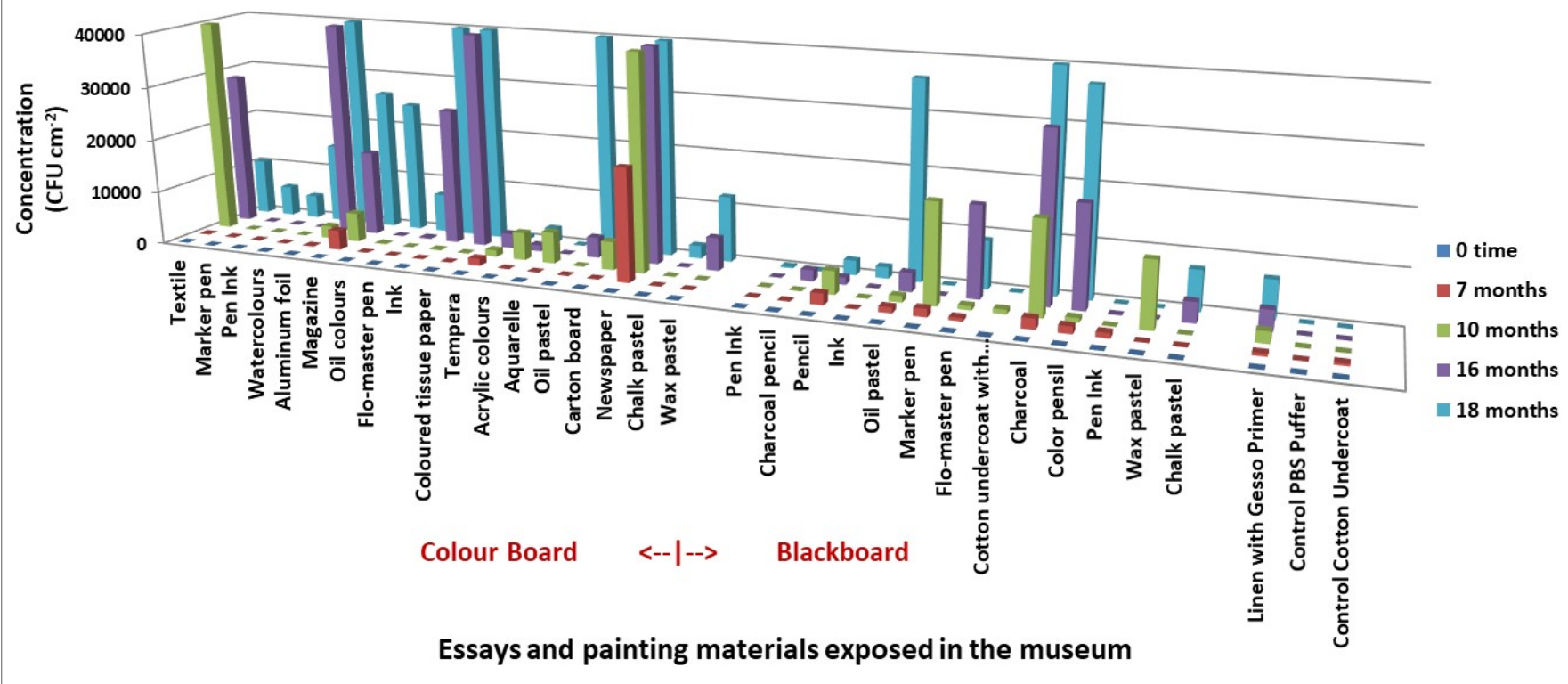

Fig. 9. Colonization of heterotrophic bacteria ( $\mathrm{CFU} \mathrm{cm}{ }^{-2}$ ) on different model essays and painting materials after an exposure period of 18 months in the museum.

Specifically, fast colonization and high concentrations of viable heterotrophic bacteria (up to $300,000 \mathrm{CFU} \mathrm{\textrm {cm } ^ { - 2 }}$ ) were measured on newspaper, magazine, textile, aluminum foil, oil colors, ink, colored tissue paper, oil pastel, carton at the color board, as well as, at surfaces covered with oil pastel, Flo-Master pen, charcoal, and color pencil at the blackboard.

In comparison, slow colonization and bacterial deposits in concentrations lower than 15,000 $\mathrm{CFU} \mathrm{\textrm {cm } ^ { - 2 }}$ were determined on watercolors, Flo-Master pen, and wax pastel at the color board, as well as on marker pen at the blackboard, and on linen coated with gesso primer.

Contrary, it was not measured significant enrichment of viable heterotrophic bacteria (earliest detection after 10 months of exposition, and growth in concentrations lower than $5,000 \mathrm{CFU} \mathrm{cm}^{-2}$ ) on surfaces painted with marker pen, pen ink, tempera, acrylic colors, aquarelle, chalk pastel of the color board, as well as, on surfaces painted with pen ink, charcoal pencil, pencil, ink and on cotton undercoat with acrylic coating of the blackboard.

Surprisingly, the analysis of the microbial colonization showed that there were not determined viable fungi deposits on 20 different essays and painting materials placed, although the yearly average concentration of the airborne fungi was measured $143 \pm 115 \mathrm{CFU} \mathrm{m}^{-3}$ in the exhibition rooms. Low concentrations ranging from 70 to $200 \mathrm{CFU} \mathrm{cm}^{-2}$ were only determined on tempera and carton essay of the color board, as well as on charcoal and wax pastel of the blackboard after 18 months' exposure. The ability of fungi to colonize surfaces depend on different factors, such as bioreceptivity, spatial orientation of sedimentation surfaces, low requirement of nutrients and energy, and environmental parameters (Urzì et al., 2001). A future study may concentrate also on the microbial colonization evaluation of different painting substrates after the deployment of air-purifying ionizer devices in order to determine their efficacy of reducing the surface concentration of microorganism deposits.

In agreement to our colonization results, studies of microbial communities adhering to the surfaces of an oil painting on canvas (López-Miras et al., 2013) reported that the dominant microbial community on the painting surface was shown to be directly related to the indoor air quality where the painting was exposed. In addition, the authors confirmed a near absence of actively growing microbes on areas of paintings showing no visible damage.

\section{CONCLUSIONS}

The ambient concentrations of the viable, cultivable airborne bacteria and fungi were measured 
both indoors and outdoors at the Historical Museum of Crete to evaluate the effect of indoor air purifiers and investigate the microbial colonization on the exposed surfaces in an exhibition room.

Large seasonal variations in the airborne microbial load were observed at the indoor sites. Also, the concentrations of the viable microbes rose during the opening hours of the museum, when visitors were present. Although the individual types of microorganisms varied in abundance by location, the total average concentrations were similar across all of the sites inside the museum. Furthermore, the average I/O ratio ranged from 1 to 92 for the different microbial groups, indicating an enrichment indoors. In particular, relatively high concentrations of acid-producing bacteria, which may cause deterioration in the museum's cultural heritage objects, were found at every site.

A comparison of the measurements obtained before and after deployment revealed that operating photocatalytic ionizers inside the museum effectively reduced the concentrations of the viable airborne microbes, thereby improving the air quality. Additionally, the adequately ventilated locations (i.e., belonging to Site B), where all exhibits were stored inside showcases, showed microbial levels comparable to those obtained outdoors. However, the efficiency of the photocatalytic ionizers in filtering bacteria also depended on the total aeration rate and the microbes' emission rates indoors. Thus, controlling the ventilation and using showcases as well as air purifiers is recommended for both improving the indoor air quality and protecting the exhibits. Because this study was limited to a specific period and did not address all of the potential factors, such as the variability of the indoor microorganisms, though, these findings should be treated with caution.

Finally, in terms of the viable fast-growing fungi, no colonization was detected on the majority of the painting substrates and materials used in the model artwork essays, which were exposed to the ambient air inside the museum for 18 months. These results demonstrate the toxicity of the paint, even in the absence of varnish, and explain the long-term preservation of paintings even in suboptimum storage conditions. However, probably owing to their chemical composition, which possibly supplied nutrients to the microbes, several of the materials, e.g., the newspaper and magazine, displayed high levels of viable heterotrophic bacteria. Surprisingly, though, even these materials showed no fungal colonization. Fungi were measured only on the tempera, charcoal, wax pastel, and carton board, where they were confined to low concentrations. The colonization patterns observed on the essay materials were likely directly related to the pre-existing microbial populations and air quality indoors: Whereas high airborne concentrations enabled the bacteria to grow on all exposed surfaces, low ones prevented the fungi from growing on almost any surface.

In summary, equipping exhibition rooms with air-purifying systems (such as photocatalytic ionizers) and microclimate-controlled showcases can reduce the populations of potentially pathogenic heterotrophic bacteria and acid-producing bacteria, which are increased by numerous anthropogenic activities. To improve the environment for both humans and cultural heritage objects, the efficiency of these relatively new technologies and practices can be enhanced by regulating HVAC systems.

\section{ACKNOWLEDGMENTS}

This work was performed under the Operational Cross-Border Cooperation Programme Greece-Cyprus 2007-2013 and was co-financed by the European Union (ERDF) (80\%) and national funds of Greece and Cyprus (20\%). Award Number: MIS 901065.

\section{DISCLAIMER}

The authors declare that they have no conflict of interest.

\section{REFERENCES}

Anaf, W., Horemans, B., Madeira, T.I., Carvalho, M.L., De Wael, K., Van Grieken, R. (2013). Effects of a constructional intervention on airborne and deposited particulate matter in the portuguese national tile museum, Lisbon. Environ. Sci. Pollut. Res. 20, 1849-1857. https://doi.org/10.100 7/s11356-012-1086-7 
ASHRAE (2003). Museums, libraries and archives, ASHRAE Handbook: Heating, Ventilating, and Air-Conditioning Applications. SI edition, Atlanta. https://www.ashrae.org/technicalresources/ashrae-handbook

ASHRAE (2011). Handbook, heating, ventilating, and air-conditioning applications. SI edition, 21.1-21.23, Atlanta. https://www.ashrae.org/technical-resources/ashrae-handbook

ASHRAE (2013). Standard 62. In: Ventilation for acceptable indoor air quality, ASHRAE Handbook ISSN 1041-2336, Atlanta. https://www.ashrae.org/technical-resources/ashrae-handbook

Bogomolova, E.V., Ivanova, A.M., Kirtsideli, I.Y., Mel'nik, V.A., Sokolenko, D.V. (2007). Micromycetes complexes on photographs from old collections (1839-1912). Topics Photogr. Preserv. 12, 5563. http://resources.culturalheritage.org/pmgtopics/2007-volume-twelve/12_11_Bogomolov a.pdf

Brągoszewska, E., Biedroń, I., Kozielska, B., Pastuszka, J.S. (2018). Microbiological indoor air quality in an office building in Gliwice, Poland: analysis of the case study. Air Qual. Atmos. Health 11, 729-740. https://doi.org/10.1007/s11869-018-0579-z

Brimblecombe, P. (1990). The composition of museum atmospheres. Atmos. Environ. 24, 1-8. https://doi.org/10.1016/0957-1272(90)90003-D

Buttner, M.P., Gruz-Perez, P., Garrett, P.J., Stelzenbach. L.D. (1999). Dispersal of fungal spores from three types of air handling system duct material. Aerobiologia 15, 1-8. https://doi.org/10. 1023/A:1007513303358

Buttner, M.P., Stelzenbach, L.D. (1993). Monitoring of fungal spores in an experimental indoor environment to evaluate sampling methods and the effects of human activity on air sampling. Appl. Environ. Microbiol. 59, 219-226. https://doi.org/10.1128/AEM.59.1.219-226.1993

Camuffo, D. (1998). Microclimate for Cultural Heritage. Elsevier, Amsterdam. eBook ISBN: 9780080536538

Cataldo, R., De Donno. A., De Nunzio, G., Leucci, G., Nuzzo, L., Siviero, S. (2005). Integrated methods for analysis of deterioration of cultural heritage: The Crypt of "Cattedrale di Otranto". J. Cult. Herit. 6, 29-38. https://doi.org/10.1016/j.culher.2004.05.004

Di Carlo, E., Chisesi, R., Barresi, G., Barbaro, S., Lombardo, G., Rotolo, V., Sebastianelli, M., Travagliato, G., Palla, F. (2016). Fungi and Bacteria in Indoor Cultural Heritage Environments: Microbial-related Risks for Artworks and Human Health. Environ. Ecol. Res. 4, 257-264. https://doi.org/10.13189/eer.2016.040504

Flieder, F., Capderou, C., Duchein, M. (1999). Sauvegarde des collections du Patrimoine: La lutte contre les détériorations biologiques (Safeguarding of heritage collections: The lute against biological deteriorations). (in French). CNRS Editions, Paris. ISBN: 9782271056160.

Gallo, F. (1993). Aerobiological research and problems in libraries. Aerobiologia 9, 117-130. https://doi.org/10.1007/BF02066253

Gauzere, C., Moletta-Denat, M., Blanquart, H., Ferreira, S., Moularat, S., Godon, J.J., Robine, (2014). Stability of airborne microbes in the Louvre Museum over time. Indoor Air 24, 29-40. https://doi.org/10.1111/ina.12053

Gauzere, C., Moletta-Denat, M., Bousta, F., Moularat, S., Orial, G., Ritoux, S., Godon, J.J., Robine, E. (2013). Reliable procedure for molecular analysis of airborne microflora in three indoor environments: An office and two different museum contexts. Clean-Soil Air Water 41, 226234. https://doi.org/10.1002/clen.201100699

Glytsos, T., Kopanakis, I., Katsivela, E., Grøntoft, T., Violaki, V., Lazaridis, M. (2018). The influence of outdoor air pollution to indoor air quality in a mechanical ventilated museum envelope. in: Adriaens, M., Bioletti, S., Rabin, I. (Eds), Chemical interactions between cultural artefacts and indoor environment, Uitgeverij ACCO press, Leuven, Belgium, pp. 173-192. http://hdl.handle. net/1854/LU-8550694

Gorny, R.L., Harkawy, A.S., Lawniczek-Walczyk, A., Karbowska-Berent, J., Wlazlo, A., Nielser, A., Golofit-Szymczak, M., Cyprowski, M. (2016). Exposure to culturable and total microbiota in cultural heritage conservation laboratories. Int. J. Occup. Med. Environ. Health 29, 255-275. https://doi.org/10.13075/ijomeh.1896.00630

Karyś, J., Ważny, J. (2007). Wood dry-rot fungi as biodegradation factors of porous building materials. Folia For. Pol. Ser. B 38, 33-40. https://ffp.matlibhax.com/pdf/38/Folia\%20Forestal ia\%20Pol\%2038-4\%20Karys\%20Wazny.pdf

Katsivela, E., Latos, E., Raisi, L., Aleksandropoulou, V., Lazaridis, M. (2017). Particle size 
distribution of cultivable airborne microbes and inhalable particulate matter in a wastewater treatment plant facility. Aerobiologia 33, 297-314. https://doi.org/10.1007/s10453-016-9470-2

Lazaridis, M., Katsivela, E., Kopanakis, I., Raisi, L., Panagiaris, G. (2015). Indoor/outdoor particulate matter concentrations and microbial load in cultural heritage collections. Herit. Sci. 3, 34-46. https://doi.org/10.1186/s 40494-015-0063-0

Lazaridis, M., Katsivela, E., Kopanakis, I., Raisi, L., Mihalopoulos, N., Panagiaris, G. (2018). Characterization of airborne particulate matter and microbes inside cultural heritage collections. J. Cult. Herit. 30, 136-146. https://doi.org/10.1016/j.culher.2017.09.018

Leibniz Institute DSMZ- German Collection of Microorganisms and Cell Cultures (2007). 105. Gluconobacter oxydans Medium. http://www.dsmz.de/microorganisms/medium/pdf/DSMZ_ Medium105.pdf (accessed 30 December 2020).

Leibniz Institute DSMZ- German Collection of Microorganisms and Cell Cultures (2012). 457. Mineral Medium (Brunner). https://www.dsmz.de/microorganisms/medium/pdf/DSMZ_Med ium457.pdf (accessed 30 December 2020).

Li, A., Xiong, J., Yao, L., Gou, L., Zhang, W. (2016). Determination of dust and microorganism accumulation in different designs of AHU system in Shaanxi History Museum. Build. Environ. 104, 232-242. https://doi.org/10.1016/j.buildenv.2016.05.014

Lightthart, B., Stelzenbach, L.D. (1994). Distribution of microbial aerosols. in: Lightthart, B., Mohr, A.J. (Eds), Atmospheric Microbial Aerosols: Theory and Applications, Chapman and Hall Inc., New York, USA, pp. 68-98. ISBN 978-1-4684-6438-2

López-Miras, M.d.M., Martín-Sánchez, I., Yebra-Rodríguez, Á., Romero-Noguera, J., BolívarGaliano, F., Ettenauer, J., Sterflinger, K., Piñar, G. (2013). Contribution of the microbial communities detected on an oil painting on canvas to its biodeterioration. PLoS One 8, e80198. https://doi:10.1371/journal.pone.0080198

Maier, R.M., Pepper, I.L., Gerba, C.P. (2000). Environmental Microbiology. Academic Press, San Diego, California. ISBN: 978-0-12-370519-8

McNamara, C.J., Breuker, M., Helms, M., Perry, T.D., Mitchell, R, (2004). Biodeterioration of Incralac used for the protection of bronze monuments. J. Cult. Herit. 5, 361-364. https://doi:10.1016/j.culher.2004.06.002

Ministry of Cultural Heritage and Activities and Tourism (MiBAC) (1998). Official guidelines on technical-scientific criteria and standards of operation and development of museums. (in Italian). Scope VI. J Laws, No. 150, item 6.

Micheluz, A., Manente, S., Prigione, V., Tigini, V., Varese, G.C., Ravagnan, G. (2018). The effects of book disinfection to the airborne microbiological community in a library environment. Aerobiologia 34, 29-44. https://doi.org/10.1007/s10453-017-9492-4

Niesler, A., Górny, R.L., Wlazło, A., Łudzeń-Izbińska, B., Ławniczek-Wałczyk, A., Gołofit-Szymczak, M., Meres, Z., Kasznia-Kocot, J., Harkawy, A., Lis, D.O., Anczyk, E. (2010). Microbial contamination of storerooms at the Auschwitz-Birkenau Museum. Aerobiologia 26, 125-133. https://doi.org/10.1007/s10453-009-9149-z

Ruga, L., Orlandi, F., Romano, B., Fornaciari, M. (2015). The assessment of fungal bioaerosols in the crypt of St. Peter in Perugia (Italy). Int. Biodeter. Biodegr. 98, 121-130. https://doi.org/10. 1016/j.ibiod.2014.12.010

Parchas, M.D. (2008). Comment faire face aux risques biologiques? (How to deal with biohazards?) (in French) Direction des Archives de France, Paris. https://francearchives.fr/file/ 99658e314af597c288bf14c9970be9d59f01d3b1/static_1895.pdf

Park, J.S., Sung, B.J., Jeong, C.S. (2016). The bactericidal effect of an ionizer under low concentration of ozone. BMC Microbiol. 16, 173. https://doi.org/10.1186/s12866-016-0785-5

Pasquarella, C., Balocco, C., Pasquariello, G., Petrone, G., Saccani, E., Manotti, P., Ugolotti, M., Palla, F., Maggi, O., Albertini, R. (2015). A multidisciplinary approach to the study of cultural heritage environments: Experience at the Palatina Library in Parma. Sci. Total Environ. 536, 557-567. https://doi.org/10.1016/j.scitotenv.2015.07.105

Petushkova, J., Kandyba, P. (1999). Aeromicrobiological studies in Moscow cathedrals. Aerobiologia 15, 193-201. https://doi.org/10.1023/A:1007546224493

Pushpawela, B., Jayaratne, R., Nguy, A., Morawska, L. (2017). Efficiency of ionizers in removing airborne particles in indoor environments. J. Electrost. 90, 79-84. https://doi.org/10.1016/j.els tat.2017.10.002 
Reynolds, S.J., Streifel, A.J., McJilton, C.E. (1990). Elevated airborne concentrations of fungi in residential and office environments. Am. Ind. Hyg. Assoc. J. 51, 601-604. https://doi.org/10.10 80/15298669091370185

Ruga, L., Orlandi, F., Romano, B., Fornaciari, M. (2015). The assessment of fungal bioaerosols in the crypt of St. Peter in Perugia (Italy). Int. Biodeter. Biodegr. 98, 121-130. https://doi.org/10. 1016/j.ibiod.2014.12.010

Stelzenbach, L.D. (2002). Introduction to aerobiology. in: Hurst, C.J., Crawford, R.L., Garland, J.L., Lipson, D.A., Mills, A.L., Stetzenbach, L.D. (Eds.), Manual of Environmental Microbiology, ASM Press, Washington DC, pp. 801-813. https://doi.org/10.1128/9781555815882

Urzì, C., De Leo, F., Salamone, P., Criseo, G. (2001). Airborne fungal spores colonising marbles exposed in the terrace of Messina Museum, Sicily. Aerobiologia 17, 11-17. https://doi.org/10. 1023/A:1007652300354 